\title{
LITERASI KEBERAGAMAAN ANAK KELUARGA MARJINAL BINAAN KOMUNITAS DI KOTA BOGOR
}

\author{
Oleh: Unang Wahidin; Yahya Muharikul Islam; Putri Fadillah \\ unang.wahidin@gmail.com
}

\begin{abstract}
Literacy Religious Children Family Marginal Community Guided in the City of Bogor. This research was conducted in Bogor city in community of foster child of marginal family. The research objectives related to the community are: 1 . describing the community profile; 2. describe the model of educational curriculum in the community; 3. describe the learning process in the community; While the research objectives related to the children of the marginal family are: 1. describing and analyzing the religious literacy of the belief dimension; 2. describe and analyze religious literacy the dimensions of religious practice; 3. describe and analyze the religious literacy of the dimensions of religious experience; and 4. to describe and analyze the religious literacy of the dimension of religious knowledge. Grand theory used is about: 1. theory of literacy; 2. religious theory; 3. theories about children, and 4. the theory of the marginal family. While the research method used is qualitative with data collection techniques: 1. active participative observation techniques; 2. structured interview techniques; and 3. documentation techniques. The results of research related to the community as follows: 1. community coaches of marginal family children in the city of Bogor is a social group that has a very important role; 2. educational system curriculum model organized by the community of mentors of marginal family children in Bogor city consists of curriculum components organized in such a way and directed to achieve educational objectives; 3. The learning process of the children of the marginalized families carried out by communities in the city of Bogor has been in accordance with the management of regular learning. While the results of research related to the children of the marginal family as follows: 1. the children of the marginal family believe all the get along contained in the pillars of faith; 2 . the child of the marginal family is capable of carrying out the practices of the religious teachings he or she believes in; 3. children of marginal families of the majority have religious experience; and 4. the majority of the children of the marginal family have knowledge of the religion they follow.
\end{abstract}

Keywords: Literacy, Religious, Children Family Marginal, Community Guided.

\section{A. Pendahuluan}

Masih banyak dari sebagian masyarakat khususnya anak-anak dari keluarga marjinal tidak cukup mendapatkan pendidikan agama dari orang tuanya. Anak-anak tersebut sejak kecil sudah dihadapkan pada permasalahan keluarga yang cukup rumit, padahal jika 
dilihat dari segi kematangan mereka belum mampu memikirkan keadaan ekonomi dan memecahkan masalah keluarga.

Penelusuran yang lebih empatik dan intensif ke dalam kehidupan anak keluarga marjinal menunjukan adanya keragaman. Keragaman itu antara lain disebabkan oleh latar belakang keluarga, lingkungan tempat tinggal, pilihan pekerjaan, pergaulan dan pola pengasuhan. Tidak mengherankan terdapat keragaman dalam pola tingkah laku, kebiasaan dan tampilan mereka.

Keadaan tersebut di atas diperparah lagi oleh kondisi orang tua anak keluarga marjinal yang sama sekali kurang memahami bahwa orang tua mempunyai peran yang wajib dilaksanakan, yaitu: mendidik, melatih, membimbing dan peran lainnya sebagai orang tua. Orang tua anak keluarga marjinal kurang menyadari bahwa anak merupakan amanah dari Allah swt yang di dalamnya ada tanggung jawab yang harus ditunaikan. Selain itu, sikap orang tua yang lebih cenderung mendorong anaknya bekerja untuk menghasilkan uang dari pada bersekolah yang dirasa hanya menghabiskan uang dan tidak menjanjikan apa-apa. Inilah yang mengakibatkan pola eksploitatif orang tua terhadap anak.

Kondisi yang dialami anak keluarga marjinal sebagaimana dipaparkan di atas harus segera dicari penyelesaiannya, karena hal ini berpengaruh besar bukan saja terhadap anak keluarga marjinal bersangkutan, melainkan juga bagi pembangunan bangsa dan negara di masa datang. Keberlanjutan bangsa dan negara ini berada pada anakanak masa kini.
Literasi keberagamaan penting ditanamkan kepada anak keluarga marjinal, sehubungan mereka selama ini kurang mendapatkan pengenalan dan penanaman agama yang seharusnya sudah tertanam kuat pada jiwa mereka sejak awal.

Pelaksanaan literasi keberagamaan anak keluarga marjinal tidak bisa terlepas dari peran lembaga, baik berupa: komunitas, lembaga pemerintah, lembaga swadaya masyarakat (LSM), lembaga keagamaan, lembaga sosial atau bentuk lembaga lain yang dibentuk oleh pemerintah maupun masyarakat.

Peran komunitas dalam literasi keberagamaan anak keluarga marjinal memegang peranan sangat penting, karena dalam komunitas berlangsung proses pendidikan, pembelajaran, pelatihan, pendampingan, perlindungan, pengembangan wawasan dan kemampuan lainnya yang selama ini kurang didapatkan anak keluarga marjinal.

Permasalahan dalam penelitian ini memandu peneliti mengeksplorasi dan memotret situasi sosial yang diteliti secara menyeluruh, luas dan mendalam. Sehingga bentuk rumusan masalah penelitian ini adalah bentuk deskriptif sebagai berikut: Bagaimanakah literasi keberagamaan anak keluarga marjinal binaan komunitas di kota Bogor?

Selanjutnya permasalahan tersebut di atas diuraikan ke dalam beberapa pertanyaan penelitian sebagai berikut:

Berkaitan dengan komunitas: 1 . Bagaimana profil komunitas yang membina anak keluarga marjinal di kota Bogor? 2. Bagaimana model kurikulum pendidikan yang diselenggarakan komunitas pembina anak keluarga marjinal 
di kota Bogor? 3. Bagaimana proses pembelajaran anak keluarga marjinal yang dilaksanakan komunitas di kota Bogor?

Sedangkan pertanyaan penelitian berkaitan dengan anak keluarga marjinal: 1. Bagaimana literasi keberagamaan anak keluarga marjinal binaan komunitas di kota Bogor yang berkaitan dengan dimensi keyakinan? 2. Bagaimana literasi keberagamaan anak keluarga marjinal binaan komunitas di kota Bogor yang berkaitan dengan dimensi praktek agama? 3. Bagaimana literasi keberagamaan anak keluarga marjinal binaan komunitas di kota Bogor yang berkaitan dengan dimensi pengalaman keberagamaan? dan 4. Bagaimana literasi keberagamaan anak keluarga marjinal binaan komunitas di kota Bogor yang berkaitan dengan dimensi pengetahuan agama?

Sehubungan dengan hal tersebut di atas, dalam penelitian ini yang diteliti adalah anak keluarga marjinal binaan komunitas Sekolah Bersama Yuk (Sebersy) dan komunitas Terminal Hujan, kedua komunitas tersebut berada di kota Bogor.

\section{B. Landasan Teori \\ 1. Literasi / Literacy}

Literasi adalah kemampuan berbahasa seseorang (menyimak, berbicara, membaca dan menulis) untuk berkomunikasi dengan cara yang berbeda sesuai dengan tujuannya. ${ }^{1}$ Sulzby mengartikan literasi secara sempit, yaitu literasi sebagai kemampuan membaca dan menulis. ${ }^{2}$ Hal ini sejalan dengan pendapat

${ }^{1}$ USAID. (2014). Pembelajaran Literasi Kelas Awal di LPTK. Buku Sumber untuk Dosen LPTK. hlm: 2

${ }^{2}$ Elizabeth Sulzby dan William H. Teale. (1986). Emergent Literacy: Writing and Reading. Ablex Pub. Corp. University of Minnesota, USA. p: 218.
Grabe \& Kaplan $^{3}$ dan Graff $^{4}$ yang mengartikan literacy sebagai kemampuan untuk membaca dan menulis (able to read and write).

Sedangkan The United Nation Educational, Scientific and Cultural Organization (UNESCO) mendefinisikan literacy sebagai "the ability to identify, understand, interpret, creat, communicate, compute and use printed and written materials associated with varying contexts". Literasi ini meliputi kontinum pembelajaran yang memungkinkan individu untuk mencapai tujuan hidup mereka, mengembangkan pengetahuan dan potensinya, dan partisipasinya secara penuh dalam kehidupan sosial mereka secara luas. Selanjutnya Deklarasi Praha pada tahun 2003 menyebutkan bahwa literasi juga mencakup bagaimana seseorang berkomunikasi dalam mas yarakat. Literasi juga bermakna praktik dan hubungan sosial yang terkait dengan pengetahuan, bahasa, dan budaya. ${ }^{5}$

Dalam konteks sekarang, literasi memiliki arti yang sangat luas, literasi bisa berarti melek teknologi, politik, berpikir kritis dan peka terhadap lingkungan sekitar. Dengan demikian, seseorang bisa dikatakan literat jika sudah memahami sesuatu karena membaca dan melakukan sesuatu berdasarkan pemahaman bacaannya. ${ }^{6}$

3 Grabe , W. and Kaplan R (Eds.). (1992). Introduction to Applied Linguistics. New York: Addison Wesley Publishing Company.

${ }^{4}$ Harvey J. Graff. (2006). Literacy. Microsoft Encarta (DVD). Redmond, WA: Microsoft Corporation 2005.

5 Unesco. (2003). The Prague Declaration. "Towards an Information Literate Society."

6 Wahyudin. (2012). Model Pembelajaran Transliterasi Sebagai Inovasi dalam Meningkatkan Kompetensi Warga Belajar 
Menurut UNESCO, seseorang disebut literat apabila ia memiliki pengetahuan yang hakiki untuk digunakan dalam setiap aktivitas yang menuntut fungsi literasi secara efektif dalam masyarakat; dan pengetahuan yang dicapainya dengan membaca, menulis dan arithmetic memungkinkan untuk dimanfaatkan bagi dirinya sendiri dan perkembangan masyarakat. 7 Untuk menjadi literat yang sesungguhnya, menurut Well, seseorang harus memiliki kemampuan menggunakan berbagai tipe teks secara tepat dan kemampuan memberdayakan pikiran, perasaan, dan tindakan dalam konteks aktivitas sosial dengan maksud tertentu. Pengertian literat itulah yang dimaksud dengan istilah "mahir wacana".

$$
\text { Melihat beberapa pengertian }
$$

literasi (literacy) di atas dapatlah disimpulkan bahwa literasi yang dimaksud bukan hanya dalam arti sempit berupa kemampuan individu dalam membaca dan menulis, melainkan meliputi kontinum pembelajaran yang memungkinkan individu dapat mencapai tujuan hidup mereka, mengembangkan pengetahuan dan potensinya, dan partisipasinya secara penuh dalam kehidupan sosial mereka secara luas.

Berkaitan dengan penelitian ini, literasi keberagamaan yang dimaksud adalah kemampun yang diperoleh individu

Pendidikan Keaksaraan Fungsional. Ringkasan Disertasi. Bandung: Universitas Pendidikan Indonesia. hlm: 13.

7 Wahyudin. (2012). Model Pembelajaran Transliterasi Sebagai Inovasi dalam Meningkatkan Kompetensi Warga Belajar Pendidikan Keaksaraan Fungsional. hlm: 13

${ }^{8}$ G. Well. (1990). Creating the Condition to Encourage Literate Thinking Educational Leadershif. hlm: 14 . sebagai hasil proses belajar dalam menganut dan melaksanakan ajaran agama yang diyakininya. Dalam penelitian ini diharapkan akan didapatkan data tentang literat (melek) keberagamaan anak keluarga marjinal binaan komunitas di kota Bogor yang berhubungan dengan dimensi keyakinan, dimensi praktek agama, dimensi pengalaman dan dimensi pengetahuan agama yang dianutnya.

\section{Keberagamaan}

Keberagamaan yang dimaksud secara bahasa adalah perihal beragama. ${ }^{9}$ Adapun secara istilah, keberagamaan merupakan perilaku beragama atau perwujudan atas keyakinan yang dimiliki seseorang. ${ }^{10}$ Dalam penelitian ini, istilah agama dimaksudkan adalah agama Islam, atau "dinullah" atau "dinul haq", yaitu agama yang datang dari Allah swt atau agama yang $h a q$.

Keberagamaan merupakan bentuk respon manusia terhadap sesuatu yang sakral. Pada keanekaan agama yang bisa dilacak pada setiap zaman, tempat, budaya dan peradaban menunjukkan bahwa manusia memiliki kecenderungan alamiah untuk percaya pada penciptanya. Keberagamaan akan berkaitan erat dengan dimensi keyakinan, dimensi praktek agama, dimensi pengalaman dan dimensi pengetahuan agama. ${ }^{11}$

Dimensi keyakinan berisikan pengharapan-pengharapan dimana orang

\footnotetext{
${ }^{9}$ Departemen Pendidikan Nasional. (2012). Kamus Besar Bahasa Indonesia. Pusat Bahasa. Edisi Keempat. hlm: 15.

${ }^{10}$ Lukman Ali. (1994). Kamus Besar Bahasa Indonesia. Jakarta: Balai Pustaka. Cet. II. hlm: 10.

11 Roland Robertson. (1988). Agama : dalam Analisa dan Interpretasi Sosiologis. terj. Achmad Fedyani Saifudin. Jakarta: CV Rajawali. Cet. I. hlm: 295-297.
} 
yang religius berpegang teguh pada pandangan teologis tertentu dan mengakui kebenaran doktrin-doktrin tersebut. Oleh karena itu setiap agama mempertahankan seperangkat kepercayaan dimana para penganutnya diharapkan taat terhadap kewajiban-kewajibannya.

Dimensi praktek keagamaan mencakup perilaku pemujaan, ketaatan dan hal-hal yang dilakukan orang untuk menunjukkan komitmen terhadap apa yang dianutnya. Praktek-praktek keagamaan ini terdiri dari ritual dan ketaatan yang mengacu pada seperangkat ritus, tindakan keagamaan formal dan praktek-praktek suci yang semua agama mengharapkan para penganutnya melaksanakan.

Dimensi pengalaman berisikan dan memperhatikan fakta bahwa semua agama mengandung pengharapan-pengharapan tertentu; bahwa ia akan mencapai suatu keadaan kontak dengan penciptanya. Setiap agama memiliki paling tidak nilai minimal terhadap sejumlah pengalaman subyektif keagamaan sebagai tanda keberagamaan individual.

Adapun dimensi pengetahuan agama mengacu kepada harapan bahwa orang-orang yang beragama paling tidak memiliki sejumlah minimal pengetahuan mengenai dasar-dasar keyakinan, ritusritus, kitab suci dan tradisi.

Keberagamaan anak keluarga marjinal dipandang masih lemah sehubungan dengan kurangnya pembinaan. Di sinilah pentingnya peranan komunitas dalam membantu anak keluarga marjinal untuk meyakini, mampu mempraktekan, memiliki pengalaman dan mengetahui agama yang dianutnya.

\section{Anak Keluarga Marjinal}

Penetapan umur untuk anak di tiap negara dan bidang kegiatan berbeda menurut kepentingan masing-masing. Di dalam Lembaran Republik Indonesia Nomor 32 menjelaskan tentang pengertian anak: ${ }^{12}$ "Anak adalah seseorang yang belum mencapai umur 21 tahun dan belum pernah kawin". Juga bisa kita lihat di dalam Kitab Undang-Undang Hukum Pidana (KUHP) menetapkan umur di bidang peradilan yaitu 16 tahun, sedangkan menurut tinjauan psikologi pada umumnya pengertian anak dibatasi sebelum menginjak masa remaja. Dalam UndangUndang lainnya seperti Undang-Undang Nomor 1 Tahun 1991, menyatakan bahwa: "Anak adalah mereka yang berusia 14 tahun ke bawah". Sebaliknya UndangUndang Perkawinan menetapkan batas usia 16 tahun.

Dilihat dari Konvensi Usia Minimum Nomor 138, terdapat pengertian anak adalah: "Seseorang yang berusia 15 tahun ke bawah". Sedangkan dalam Konvensi Hak-Hak Atas Anak tahun 1989, disebutkan bahwa "anak adalah mereka yang berusia 18 (delapanbelas) tahun ke bawah". Konvensi Hak-Hak Atas Anak ini telah diratifikasi oleh Indonesia melalui Keputusan Presiden Nomor 39 Tahun 1990.

UNICEP mendefinisikan anak adalah penduduk yang berusia antara usia 0 (nol) hingga 18 tahun. Sementara itu pada sejumlah negara berkembang batas usia anak cenderung semakin pendek. Beberapa diantaranya menetapkan usia anak di bawah 18 tahun. Apabila kita cermati, secara keseluruhan dapat dilihat

12 Undang-Undang Republik Indonesia. No. 4. Tahun 1979. Bab I Pasal 2. Kesejahteraan Anak. 
bahwa usia anak adalah usia 0 (nol) hingga 21 tahun.

Keluarga adalah unit pertama dan institusi dalam masyarakat, dimana hubungan yang terdapat di dalamnya sebagian besar sifatnya berupa hubunganhubungan langsung. Di situ pulalah berkembangnya individu dan di situlah terbentuknya tahap-tahap awal permasyarakatan (socialization) dan mulai interaksi dengannya, ia memperoleh pengetahuan, keterampilan, minat, nilainilai emosi dan sikapnya dalam hidup, dan dengan itu ia memperoleh ketentraman dan ketenangan. Keluarga adalah pokok pertama yang mempengaruhi pendidikan seseorang. Lembaga keluarga adalah lembaga yang kuat berdiri di seluruh penjuru dunia sejak zaman dahulu. Ia merupakan tempat manusia mula-mula digembleng untuk mengarungi hidupnya.

Menurut Hammudah Abd Al-Ati definisi keluarga dilihat secara operasional adalah: suatu struktur yang bersifat khusus satu sama lain, dalam keluarga itu mempunyai ikatan apakah lewat hubungan darah atau pernikahan. Menurut definisi di atas, keluarga diikat oleh dua hubungan, yaitu hubungan darah dan hubungan pernikahan. $^{13}$

Keluarga sering disebut sebagai lembaga pertama dan utama bagi pendidikan anak-anak yang dilahirkan. Disebut lembaga pertama, karena setiap anak manusia yang dilahirkan pasti berada dalam sebuah keluarga dan menerima pendidikan pertama dari keluarga sebelum lembaga-lembaga pendidikan lainnya. Pendidikan pertama yang diberikan sesuai dengan sistem pendidikan yang berlaku

\footnotetext{
${ }^{13}$ Ramayulis. Et.al. (2001). Pendidikan Islam dalam Rumah Tangga. Jakarta: Kalam Mulia.
}

dimana keluarga tersebut berada. Dan keluarga disebut lembaga utama dalam pendidikan anak, karena keluarga memegang peranan paling penting dalam pendidikan anak yang dilahirkan bila dibandingkan dengan lembaga-lembaga lainnya. ${ }^{14}$

Marjinal secara bahasa adalah tidak terlalu menguntungkan. ${ }^{15}$ Keluarga marjinal adalah keluarga miskin yang tidak terlalu menguntungkan dalam kehidupannya. Keluarga ini dalam memenuhi kebutuhan hidupnya mencari nafkah sebagai pemulung, kuli, pengamen, buruh dan pengemis.

Penjelasan siapa anak keluarga marjinal yang kini dibicarakan adalah anak yang terpaksa dan atau dipaksa untuk bekerja dan mencari penghidupan oleh orang tuanya atau oleh keadaan, utamanya karena masalah-masalah yang berkaitan dengan kemiskinan.

\section{Komunitas}

Komunitas secara bahasa diartikan sebagai kelompok organisme yang hidup dan saling berinteraksi di daerah tertentu. ${ }^{16}$ Sedangkan secara istilah, komunitas diartikan sebuah kelompok sosial dari beberapa organisme yang berbagi lingkungan, umumnya memiliki ketertarikan dan habitat yang sama. Dalam komunitas manusia, individu-individu di

14 Unang Wahidin. (2012). Peran Strategis Keluarga dalam Pendidikan Anak. Edukasi Islami. Jurnal Pendidikan Islam. ISSN 22528970. Volume 01. Issue 02. hlm. 123. STAI Al Hidayah Bogor.

15 Departemen Pendidikan Nasional. (2012). Kamus Besar Bahasa Indonesia. Pusat Bahasa. Edisi Keempat. hlm: 879.

16 Departemen Pendidikan Nasional. (2012). Kamus Besar Bahasa Indonesia. Pusat Bahasa. Edisi Keempat. hlm: 722. 
dalamnya dapat memiliki maksud, kepercayaan, sumber daya, preferensi, kebutuhan, risiko, kegemaran dan sejumlah kondisi lain yang serupa. Komunitas berasal dari bahasa Latin communitas yang berarti "kesamaan", kemudian dapat diturunkan dari communis yang berarti "sama, publik, dibagi oleh semua atau banyak". ${ }^{17}$

Menurut Crow dan Allan, Komunitas dapat terbagi menjadi tiga komponen: ${ }^{18}$

a. Berdasarkan Lokasi atau Tempat, wilayah atau tempat sebuah komunitas dapat dilihat sebagai tempat di mana sekumpulan orang mempunyai sesuatu yang sama secara geografis. Dan saling mengenal satu sama lain sehingga tercipta interaksi dan memberikan konstribusi bagi lingkungannya;

b. Berdasarkan Minat, sekelompok orang yang mendirikan suatu komunitas karena mempunyai ketertarikan dan minat yang sama, misalnya agama, pekerjaan, suku, ras, hobi maupun berdasarkan kelainan seksual. Komunitas berdasarkan minat memiliki jumlah terbesar karena melingkupi berbagai aspek; dan

c. Berdasarkan Komuni, komuni dapat berarti ide dasar yang dapat mendukung komunitas itu sendiri. Peran komunitas bagi individu-individu yang ada di dalamnya menjadi yang sangat penting, bukan saja karena adanya kesamaan diantara mereka namun juga memberikan suatu harapan yang lebih

\footnotetext{
17 Wenger. (2002). hlm. 4. https://id.wikipedia.org/wiki/Komunitas/Minggu/ 6 November 2016/pkl.14.18.

${ }^{18}$ Crow dan Allan. https://id.wikipedia.org/wiki/Komunitas/Minggu/ 6 November2016/pkl.14.18.
}

baik untuk mereka di masa yang akan datang.

Komunitas pembina anak keluarga marjinal memiliki peran yang sangat penting, bukan saja sebagai wadah untuk saling bertemu sesama anak keluarga marjinal, melainkan juga komunitas sebagai sumber bagi pengembangan kompetensi dan wawasan anak keluarga marjinal yang memberikan harapan untuk masa depan yang lebih baik.

\section{Metodologi Penelitian}

Penelitian ini menggunakan pendekatan kualitatif, hal ini sehubungan dengan objek yang diteliti adalah berupa seluruh situasi sosial baik berupa tempat, pelaku dan aktivitas yang berinteraksi secara sinergis yang berada dan terjadi di dalam komunitas pembina anak keluarga marjinal. Teknik pengumpulan data yang digunakan adalah teknik observasi partisipatif aktif; teknik wawancara terstruktur; dan teknik dokumentasi. Dalam teknik analisa data, peneliti mendeskripsikan data maupun fakta baik berbentuk kata, gambar dan peristiwa yang diperoleh, sehingga dapat mudah difahami dan temuannya dapat diinformasikan kepada pembaca.

Teknik sampling yang digunakan dalam penelitian ini adalah purposive sampling. Teknik ini digunakan peneliti dalam penentuan sumber data dengan pertimbangan tertentu. yaitu: 1 . Penanggungjawab kurikulum yang diduga mampu memberikan data yang diperlukan peneliti; 2. Anak keluarga marjinal binaan komunitas, dimana dibatasi usianya sehubungan dengan pertimbangan kemampuan memahami pertanyaan yang diberikan peneliti sehingga jawaban yang 
diberikan diharapkan lebih valid, yaitu terdiri dari: a. Anak keluarga marjinal usia 10 tahun sampai 12 tahun (seusia siswa Sekolah Dasar kelas IV sampai VI); dan b. Anak keluarga marjinal usia 13 tahun sampai 15 tahun (seusia siswa SMP/sederajat kelas VII sampai kelas IX).

\section{Hasil Penelitian}

\section{Berkaitan dengan komunitas:}

1. Profil komunitas yang membina anak keluarga marjinal di kota Bogor terdiri dari lembaga yang sudah berbadan hukum berupa yayasan maupun yang belum berbadan hukum. Tetapi semuanya memiliki: visi, misi, tujuan, legalitas, kantor dengan alamat yang jelas, susunan pengurus dengan pembagian tugas yang jelas, program kerja dan evaluasi terhadap pelaksanaannya, sumber dana dan peruntukannya, prestasi yang pernah diraih, dan data anak keluarga marjinal yang menjadi binaan.

2. Model kurikulum pendidikan yang diselenggarakan komunitas pembina anak keluarga marjinal di kota Bogor pada dasarnya menyerupai kurikulum pendidikan formal. Hal ini dapat dilihat dari komponen-komponen kurikulum yang terdapat dalam sistem pendidikan yang diselenggarakan komunitas tersebut, yaitu berupa: a. menggunakan silabus, b. adanya tujuan pembelajaran, c. menggunakan rencana pembelajaran, d. terdapat materi pembelajaran yang diberikan, e. penggunaan metode pembelajaran, f. penggunaan media pembelajaran, g. adanya strategi penilaian, h. terdapat sumber pembelajaran, i. dilaksanakannya evaluasi pembelajaran, j. terdapat jadwal pembelajaran, dan k. dilakukannya penutupan pembelajaran. Komponen-komponen kurikulum tersebut diorganisasi sedemikian rupa oleh komunitas dalam rangka pencapaian tujuan pendidikan yang direncanakan.

3. Memperhatikan deskripsi proses pembelajaran anak keluarga marjinal yang dilaksanakan di komunitas, pada dasarnya proses pembelajaran yang diselenggarakan memiliki kesamaan dengan pengelolaan pembelajaran yang dilaksanakan pada sekolah formal. Dimana pada deskripsi proses pembelajaran anak keluarga marjinal yang dilaksanakan di dua komunitas tersebut terbagi dalam tahap-tahap, yaitu:

a. Tahap sebelum pembelajaran (prainstruksional), adalah tahapan yg ditempuh pada saat memulai proses belajar mengajar (apersepsi), berupa kegiatan

guru/kakak pengajar/volunteer/sukarelawan:

1) Menanyakan kehadiran peserta didik dan mencatat siapa yang tidak hadir,

2) Bertanya kepada peserta didik sampai dimana pembahasan pelajaran sebelumnya,

3) Mengajukan pertanyaan kepada peserta didik berkaitan dgn pelajaran yang sudah diberikan sebelumnya,

4) Memberi kesempatan kepada peserta didik untuk bertanya mengenai bahan pelajaran yang belum dikuasainya dari pelajaran yang sudah diberikan, 
5) Mengulang secara singkat bahan pelajaran yang telah dibahas sebelumnya.

b. Tahap instruksional (inti), adalah tahapan pembelajaran berupa kegiatan guru/kakak pengajar/volunteer/sukarelawan:

1) Menjelaskan kepada peserta didik tujuan pengajaran yang harus dicapai setelah peserta didik mempelajari pokok materi yang akan dibahas,

2) Menjelaskan pokok materi yang akan dibahas hari itu,

3) Membahas pokok materi yang telah dijelaskan tadi,

4) Pada setiap pokok materi yang dibahas diberikan contoh-contoh konkrit,

5) Penggunaan alat bantu pembelajaran untuk memperjelas pembahasan pokok materi,

6) Menyimpulkan hasil pembahasan dari semua pokok materi.

c. Tahap evaluasi dan tindak lanjut. Tahapan ini bertujuan untuk mengetahui tingkat keberhasilan dari tahapan kedua (tahap instruksional) berupa kegiatan guru/kakak pengajar/volunteer/sukarelawan:

1) Mengajukan pertanyaan mengenai semua pokok materi yang telah dibahas pada tahapan kedua (tahap instruksional),

2) Untuk memperkaya pengetahuan peserta didik berkaiatan dengan materi yang dibahas, peserta didik diberikan tugas,

3) Mengakhiri pelajaran dengan menjelaskan/memberi tahu pokok materi yang akan dibahas pada pelajaran berikutnya.

\section{Berkaitan dengan anak keluarga marjinal:}

1. Memperhatikan hasil wawancara terstruktur berkaitan dengan literasi keberagamaan anak keluarga marjinal pada dimensi keyakinan (ideologis dimension), bahwa anak keluarga marjinal meyakini seluruh rukun yang terkandung dalam rukun iman. Keyakinan ini tumbuh sebagai hasil dari proses pembelajaran anak keluarga marjinal, baik yang dilakukan di dalam keluarga, di dalam satuan pendidikan formal maupun di dalam komunitas. Kondisi marjinal dalam bidang ekonomi, tidak mempengaruhi orang tua anak keluarga marjinal untuk terus menanamkan keyakinan akan agama yang dianutnya. Selain itu, anak keluarga marjinal memiliki kemauan untuk terus belajar tentang agama yang diyakininya itu. Keyakinan (ideologis dimension) yang sudah tertanam pada diri anak keluarga marjinal harus terus dikembangkan, sehingga keyakinan ini tidak mengalami kelunturan di kemudian hari. Agama sebagai sebuah sistem keyakinan, berisikan ajaran dan petunjuk bagi para penganutnya supaya selamat dalam kehidupan setelah mati. Karena itu juga, keyakinan keagamaan dapat dilihat sebagai orientasi pada masa yang akan datang, dengan cara mengikuti kewajiban-kewajiban keagamaan dalam kehidupan sehari-hari, sesuai dengan agama yang dianut atau diyakininya. ${ }^{19}$ Keberagamaan merupakan perilaku

\footnotetext{
${ }^{19}$ Roland Robertson(ed). (1988). Agama: dalam Analisa dan Interpretasi Sosiologis, terj. Achmad Fedyani Saifudin. Jakarta: CV Rajawali. Cet. I. hlm. VII
} 
beragama atau perwujudan atas keyakinan yang dimiliki seseorang. ${ }^{20}$ Keyakinan berisikan kepercayaan dan harapan-harapan dimana orang yang beragama berpegang teguh pada pandangan agama yang diyakininya dan mengakui kebenaran doktrin-doktrin agamanya. Oleh karena itu, setiap agama mengajarkan seperangkat kepercayaan dimana para penganutnya diharapkan yakin dan taat terhadap kewajibankewajiban dan menjauhi segala larangannya.

2. Merujuk pada hasil wawancara terstruktur berkaitan dengan keberagamaan anak keluarga marjinal pada dimensi praktek keagamaan (ritualitic dimension), dapatlah disimpulkan bahwa anak keluarga marjinal mampu melaksanakan praktekpraktek ajaran agama yang diyakininya. Hal ini tentu tidak terlepas dari peran orang tua, satuan pendidikan formal maupun komunitas di dalam membelajarkan praktek-praktek ajaran agama kepada anak keluarga marjinal. Pada dimensi praktek keagamaan (ritualitic dimension) yang mencakup perilaku pemujaan, ketaatan dan hal-hal yang dilakukan oleh anak keluarga marjinal merupakan implementasi dari komitmen mereka terhadap pelaksanaan ajaran agama yang dianutnya. Praktekpraktek keagamaan tersebut berupa ritual dan ketaatan yang mengacu pada seperangkat ritus, tindakan keagamaan formal dan praktek-praktek suci yang semua agama mengharapkan para penganut melaksanakannya.

${ }^{20}$ Lukman Ali. (1994). Kamus Besar Bahasa Indonesia. Jakarta: Balai Pustaka. Cet. II. hlm: 10.
3. Berdasarkan pada hasil wawancara terstruktur berkaitan dengan dimensi pengalaman keberagamaan (experiental dimension), anak keluarga marjinal binaan komunitas di kota Bogor mayoritas memiliki pengalaman keberagamaan. Pengalaman keberagamaan pada anak keluarga marjinal berisikan pengharapanpengharapan tertentu, bahwa mereka akan mencapai suatu keadaan kontak dengan Allah swt. Hal ini karena setiap agama memiliki paling tidak nilai minimal terhadap sejumlah pengalaman subyektif keagamaan setiap penganutnya sebagai tanda keberagamaan individualnya.

4. Merujuk pada data hasil wawancara terstruktur berkaitan dengan keberagamaan anak keluarga marjinal pada dimensi pengetahuan agama (intellectual dimension), terlihat bahwa mayoritas anak keluarga marjinal memiliki pengetahuan tentang agama yang dianutnya. Hal ini sebagaimana yang dikatakan Roland Robertson (ed $)^{21}$ bahwa dimensi pengetahuan agama mengacu kepada harapan bahwa orang-orang yang beragama paling tidak memiliki sejumlah minimal pengetahuan mengenai dasardasar keyakinan, ritus-ritus, kitab suci dan tradisi.

\section{Daftar Pustaka}
Ali, Lukman. (1994). Kamus Besar Bahasa Indonesia. Jakarta: Balai Pustaka. Cet. II.
Crow dan Allan. https://id.wikipedia.org/wiki/Komunitas/Min
ggu/6 November2016/pkl.14.18.

\footnotetext{
${ }^{21}$ Roland Robertson (ed). (1988). Agama : dalam Analisa dan Interpretasi Sosiologis, terj. Achmad Fedyani Saifudin. Jakarta: CV Rajawali. Cet. I. hlm. 295-297.
} 
Departemen Pendidikan Nasional. (2012). Kamus Besar Bahasa Indonesia. Pusat Bahasa. Edisi Keempat.

Graff, Harvey, J. (2006). Literacy. Microsoft Encarta (DVD). Redmond, WA: Microsoft Corporation 2005.

G. Well. (1990). Creating the Condition to Encourage Literate Thinking Educational Leadershif.

Ramayulis. Et.al.(2001). Pendidikan Islam dalam Rumah Tangga. Jakarta: Kalam Mulia.

Robertson, Roland. (1988). Agama : dalam Analisa dan Interpretasi Sosiologis. terj. Achmad Fedyani Saifudin. Jakarta: CV Rajawali. Cet. I.

Sulzby, Elizabeth dan William H. Teale. (1986). Emergent Literacy: Writing and Reading . Ablex Pub. Corp. University of Minnesota, USA.

Undang-Undang Republik Indonesia. No. 4. Tahun 1979. Bab I Pasal 2. Kesejahteraan Anak.
Unesco. (2003). The Prague Declaration.

"Towards an Information Literate Society."

USAID. (2014). Pembelajaran Literasi Kelas Awal di LPTK. Buku Sumber untuk Dosen LPTK.

Wahidin, U. (2012). PERAN STRATEGIS KELUARGA DALAM PENDIDIKAN

ANAK. Edukasi Islami: Jurnal Pendidikan Islam, 1(01).

Wahyudin. (2012). Model Pembelajaran Transliterasi Sebagai Inovasi dalam Meningkatkan Kompetensi Warga Belajar Pendidikan Keaksaraan Fungsional. Ringkasan Disertasi. Bandung: Universitas Pendidikan Indonesia.

Wenger. $\quad$ (2002). hlm. 4. https://id.wikipedia.org/wiki/Komunitas/Min ggu/6 November 2016/pkl.14.18.

W., Grabe and Kaplan, R. (Eds.). (1992). Introduction to Applied Linguistics. New York: Addison Wesley Publishing Company. 